\title{
To the knowledge of leaf beetles (Coleoptera: Chrysomelidae) from Turkey
}

\section{К познанию АистоеАов (Coleoptera: Chrysomelidae) Турции}

\author{
L.N. Medvedev

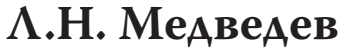

A.N. Severtsov Institute of Ecology and Evolution, Russian Academy of Sciences, Leninsky prospect, 33, Moscow 119071 Russia. E-mail: lev.n.medvedev@mail.ru

Институт проблем экологии и эволюции им. А.Н. Северцова РАН, Аенинский пр., 33, Москва 119071 Россия

Key words: Coleoptera, Chrysomelidae, Turkey, taxonomy, new subspecies, synonymy.

Ключевые слова: Coleoptera, Chrysomelidae, Турция, таксономия, новый подвиА, синонимия.

Abstract. A list of 42 species is given, 3 species are firstly recorded for Turkey. A new subspecies Cryptocephalus rugicollis ottomana subsp. n. is described, and a new synonymy is established: Orsodacne humeralis Latreille, 1804 = Orsodacne variabilis Baly, 1877, syn. n. = Orsodacne humeralis ruficollis Pic, 1895, syn. n.

Резюме. ПривеАен список из 42 видов Аистоедов, из которых 3 вида указаны Аля Турции впервые. Описан новый подвиА Cryptocephalus rugicollis ottomana subsp. n., установцена новая синонимия: Orsodacne humeralis Latreille, $1804=$ Orsodacne variabilis Baly, 1877, syn. n. = Orsodacne humeralis ruficollis Pic, 1895, syn. n.

Thanks to amiability of Dr. Maxim Nabozhenko (Institute of Arid Zones SSC RAS, Rostov-on-Don, Russia) I have an opportunity to study interesting material of Chrysomelidae collected in Turkey in 20092014. It includes 42 species, among them 3 species are firstly found in this country, and one new subspecies is described. Besides, a population of Gonioctena linnaeana (Schrank, 1781) very possibly belongs to a new subspecies. Investigation of one species from the genus Derocrepis Weise,1883 allows me to discuss taxonomic problems connected with this genus.

All data about distributions of a few species cited below are based on Catalogue of Palaearctic Coleoptera [2010].

The studied material including types of the new subspecies is deposited in the author's collection.

\section{A taxonomical list of species}

\section{Orsodacne humeralis Latreille, 1804}

Material. Tokat, Devici Dağ, 8 km E Kızılınış pass, 25-26.04.2008, 3 ex. (leg. M.V. Nabozhenko); Çanakkale Prov., Kazdağı, $39^{\circ} 44^{\prime} 756^{\prime \prime} \mathrm{N} /$ $26^{\circ} 53^{\prime} 199^{\prime \prime}$ E, 1266 m, 25.05.2009, 7 ex. (leg. M.V. and S.V. Nabozhenko, B. Keskin).

Remarks. 10 specimens of this species from East and South-East Turkey are represented with color forms:

1. Upperside entirely fulvous -3 ex.

2. Same, but prothorax with black spot or short stripe in middle -3 ex.
3. Prothorax black with fulvous stripes on sides, elytra fulvous with darkened suture -1 ex.

4. Prothorax black, elytra fulvous with darkened suture -1 ex.

5. Prothorax fulvous with dark central stripe, elytra black with violaceous tint -2 ex.

Orsodacne variabilis Baly, 1877 from "Kurdistan" is quite identical with color form 5 , mentioned above. I have also same specimen from Iraq. Orsodacne humeralis ruficollis Pic, 1895 from Iran, Syria, and Lebanon is also identical with form 5 , only without dark stripe on prothorax. Both these taxa have aedeagus quite identical with $O$. humeralis and are new synonyms of this species, so new synonymy is established: Orsodacne humeralis Latreille, 1804 = Orsodacne variabilis Baly, 1877, syn. n. = Orsodacne humeralis ruficollis Pic, 1895, syn. n.

Oulema melanopus (Linnaeus, 1758)

Material. Kayseri Prov., Devili Distr., Çadıryeri, $38^{\circ} 10^{\prime} 52.2^{\prime \prime} \mathrm{N} /$ $35^{\circ} 56^{\prime} 42.8^{\prime \prime} \mathrm{E}, 1730 \mathrm{~m}, 15.04 .2014,1$ \% (leg. M.V. and S.V. Nabozhenko, B. Keskin)

Labidostomis asiatica Faldermann, 1837

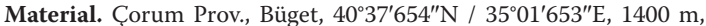
4.06.2009, 2 ex. (leg. M.V. and S.V. Nabozhenko, B. Keskin, I.V. Shokhin).

Labidostomis propinqua Faldermann, 1837

Material. Denizli Prov., Pamukkale, 12-14.2007, 1 ex. (leg. M.V. Nabozhenko); Antalya Prov., Korkuteli Distr., Ulucak, 36 $58^{\prime} 707^{\prime \prime} \mathrm{N} /$ 30 09'691"E, $1111 \mathrm{~m}, 10.05 .2009,2$ ex. (leg. M.V. and S.V. Nabozhenko, B. Keskin); Isparta Prov., coast of Beyșehir Gölü, $37^{\circ} 55^{\prime} 22^{\prime \prime} \mathrm{N} / 31^{\circ} 18^{\prime} 15^{\prime \prime} \mathrm{E}$, 14.05.2009, 3 ex. (leg. M.V. and S.V. Nabozhenko, B. Keskin); Konya Prov., Derbent Distr., Yunuslar, $37^{\circ} 53^{\prime} \mathrm{N} / 3^{\circ} 55^{\prime} \mathrm{E}, 1300 \mathrm{~m}, 15.05 .2009$, 3 ex. (leg. M.V. and S.V. Nabozhenko, B. Keskin); Bilecik Prov., Pazaryeri Distr., Sarıdayı, 39 $55^{\prime} 981^{\prime \prime} \mathrm{N} / 29^{\circ} 50^{\prime} 782^{\prime \prime} \mathrm{E}, 1178 \mathrm{~m}, 23.05 .2009,2$ ex. (leg. M.V. and S.V. Nabozhenko, B. Keskin).

Labidostomis brevipennis Faldermann, 1837

Material. Isparta Prov., coast of Beysehir Gölü, $37^{\circ} 55^{\prime} 22^{\prime \prime} \mathrm{N}$ / $31^{\circ} 18^{\prime} 15^{\prime \prime}$ E, 14.05.2009, 2 ex. (leg. M.V. and S.V. Nabozhenko, B. Keskin); Muş Prov., Varto, $39^{\circ} 07^{\prime} \mathrm{N} / 41^{\circ} 27^{\prime} \mathrm{E}, 1450 \mathrm{~m}, 16-17.05 .2009,3$ ex. (leg. I.V. Shokhin, D.G. Kasatkin); Muş Prov., Buğlan Pass, 7 km E Solhan, $38^{\circ} 56^{\prime} \mathrm{N} / 41^{\circ} 07^{\prime} \mathrm{E}, 1725-1930 \mathrm{~m}, 19-22.05 .2009,1$ ex. (leg. I.V. Shokhin, 

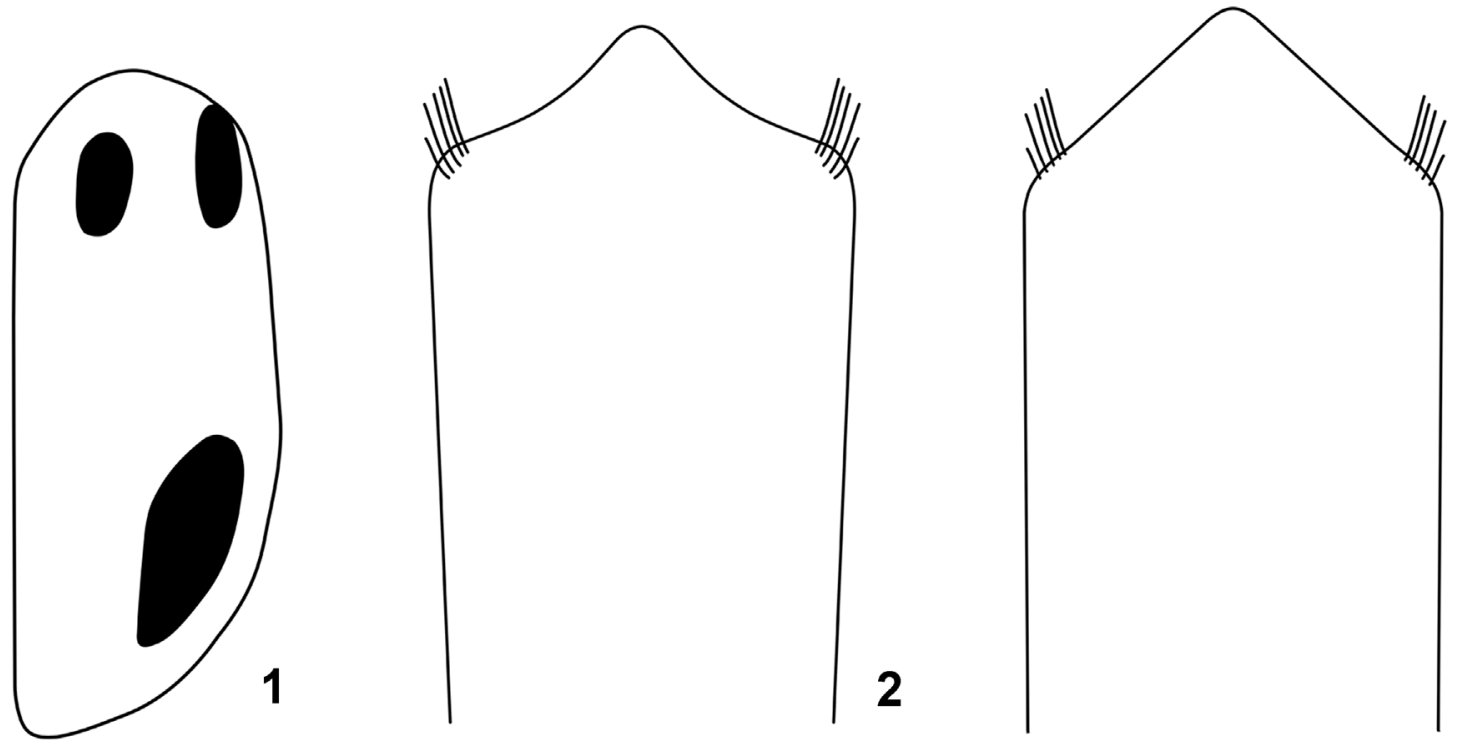

Figs 1-3. Cryptocephalus rugicollis ottomana subsp. n. (1-2) and Cryptocephalus rugicollis Olivier, 1791 (3), details of structure. 1 - elytral pattern; $2-3$ - aedeagus.

Рис. 1-3. Cryptocephalus rugicollis ottomana subsp. n. (1-2) и Cryptocephalus rugicollis Olivier, 1791 (3), Аетали строения.

1 - рисунок на надкрыльях; 2-3 - эдеагус.

D.G. Kasatkin); Çanakkale Prov., Kazdağı, 3944'756"N / 26 53'199"E, 1266 m, 25.05.2009, 1 ex. (leg. M.V. and S.V. Nabozhenko, B. Keskin); Tunceli Prov., Pülümür, 28-29.05.2009, 2 ex. (leg. I.V. Shokhin, D.G. Kasatkin); Van Prov., Erekdağ, $38^{\circ} 25^{\prime} 53.1^{\prime \prime} \mathrm{N} / 43^{\circ} 29^{\prime} 03.6^{\prime \prime} \mathrm{E}, 2077-2600$ m, 1.06.2013, 2 ex. (leg. M.V. and S.V. Nabozhenko, B. Keskin, A. Pektaș).

\section{Macrolenes dentipes (Olivier, 1808)}

Material. İzmir Prov., Çeşme, Altınkum, coast of Aegean Sea, $38^{\circ} 16^{\prime} \mathrm{N} / 26^{\circ} 16^{\prime} \mathrm{E}, 1-2.06 .2010,2$ ex. (leg. M.V. and S.V. Nabozhenko, B. Keskin).

\section{Lachnaia sexpunctata (Scopoli, 1763)}

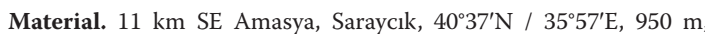
31.05-2.06.2009, 1 ex. (leg. I.V. Shokhin).

\section{Smaragdina hypocrita (Lacordaire, 1848)}

Material. Bilecik Prov., Pazaryeri Distr., Sarıdayı, 395 $55^{\prime} 981^{\prime \prime} \mathrm{N}$ 29 50'782"E, 1178 m, 23.05.2009, 1 ex. (leg. M.V. and S.V. Nabozhenko, B. Keskin); İzmit Prov., Gebze Distr., Tavşanll, 23-24.04.2014, 5 ex. (leg M.V. and S.V. Nabozhenko).

\section{Smaragdina limbata (Steven, 1806)}

Material. Aydın Prov., Nazilli Distr., Çobanlar, $37^{\circ} 59^{\prime} 881^{\prime \prime} \mathrm{N} / \mathrm{E}$ $28^{\circ} 13^{\prime} 908^{\prime \prime}$ E, $949 \mathrm{~m}, 5.05 .2009,2$ ex. (leg. M.V. and S.V. Nabozhenko, B. Keskin).

\section{Smaragdina tibialis (Brullé, 1832)}

Material. İzmit Prov., Gebze Distr., Tavşanll, 23-24.04.2014, 4 ex. (leg. M.V. and S.V. Nabozhenko).

\section{Smaragdina vaulogeri (Pic, 1894)}

Material. Muș Prov., Varto, $39^{\circ} 07^{\prime} \mathrm{N} / 41^{\circ} 27^{\prime} \mathrm{E}, 1450 \mathrm{~m}, 16-17.05 .2009$ 1 ex. (leg. I.V. Shokhin, D.G. Kasatkin).
Smaragdina djebellina (Lefèvre, 1872)

Material. Hakkari Prov., Yuksekova, $37^{\circ} 37^{\prime} 08.3^{\prime \prime} \mathrm{N} / 44^{\circ} 21^{\prime} 33.2^{\prime \prime} \mathrm{E}$, $2000 \mathrm{~m}, 5.06 .2013,1$ ex. (leg. M.V. and S.V. Nabozhenko, B. Keskin, A. Pektaş).

Remark. The species is firstly recorded for Turkey, was known from Syria, Lebanon, Israel and Jordan.

\section{Cryptocephalus concolor Suffrian, 1847}

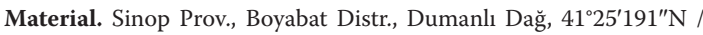
$34^{\circ} 43^{\prime} 450^{\prime \prime}$, $938 \mathrm{~m}, 1.06 .2009,1$ ex. (leg. M.V. and S.V. Nabozhenko, B. Keskin).

Remark. The species is firstly recorded for Turkey, was known from Armenia, Azerbaijan and Northern Iran.

\section{Cryptocephalus peyroni Marseul, 1875}

Material. Sinop Prov., Boyabat Distr., Dumanlı Dağ, $41^{\circ} 25^{\prime} 191^{\prime \prime} \mathrm{N} /$ $34^{\circ} 43^{\prime} 450^{\prime \prime}$ E, $938 \mathrm{~m}, 1.06 .2009$, 1 ex. (leg. M.V. and S.V. Nabozhenko, B. Keskin); İzmit Prov., Gebze Distr., Tavşanlı, 23-24.04.2014, 2 ex. (leg. M.V. and S.V. Nabozhenko).

\section{Cryptocephalus rugicollis ottomana subsp. $\mathbf{n}$.}

(Figs 1-2)

Material. Holotype, ơ: Turkey, Denizli Prov., Pamukkale, 1214.04.2007 (leg. M.V. Nabozhenko). Paratypes: 1ㅇ, same locality and date; $1 \delta$, Turkey, Manisa Prov., Soma, 21.04.1990 (leg. A. Podlussány).

Description. Color practically same as in nominative form, elytra with all three spots well developed (Fig. 1). Punctures of prothorax very feebly, almost indistinctly strigose, other structures of body are same as in nominative form. Aedeagus with sides of apical triangle are straight (Fig. 2). Length of male 3.7-4.1 mm, of female $4.7 \mathrm{~mm}$.

Diagnosis. The subspecies differs from the nominative subspecies in the sculpture of prothorax and form of aedeagus. In the nominative subspecies prothorax is distinctly strigose and sides of apical triangle of aedeagus 
are concave (Fig. 3). Also all three known specimens from Turkey have well developed elytral spots.

Nominative subspecies is distributed in Northern Africa (Algeria, Morocco) and European western Mediterranean area from Portugal to Italy. An indication from Jordan [Lopatin, Chikatunov, 1997] very possibly belongs to the described subspecies.

\section{Chrysolina reitteri pseudolurida (Roubal, 1917)}

Material. Denizli Prov., Pamukkale, 12-14.04.2007, 2 ex. (leg. M.V. Nabozhenko); Çorum Prov., Büget, 40³7'654"N / 3501'653" E, 1400 m, 4.06.2009, 1 ex. (leg. M.V. and S.V. Nabozhenko, B. Keskin, I.V. Shokhin);

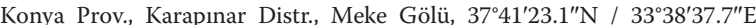
990 m, 17.05.2010, 2 ex. (leg. M.V. and S.V. Nabozhenko, B. Keskin); Malatya Prov., subdesert, 38 $38^{\prime} 48.9^{\prime \prime} \mathrm{N} / 38^{\circ} 19^{\prime} 44.1^{\prime \prime} \mathrm{E}, 740 \mathrm{~m}, 21.05 .2010$ 1 ex. (leg. M.V. and S.V. Nabozhenko, B. Keskin); Çorum Prov., Boğazkale,

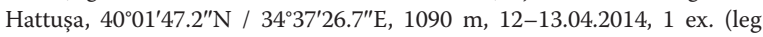
M.V. and S.V. Nabozhenko, B. Keskin).

\section{Chrysolina hyperici (Forster, 1771)}

Material. Sinop Prov., Boyabat Distr., Dumanlı Dağ, $41^{\circ} 25^{\prime} 191^{\prime \prime} \mathrm{N}$ $34^{\circ} 43^{\prime} 450^{\prime \prime} \mathrm{E}, 938 \mathrm{~m}, 1.06 .2009$, 1 ex. (leg. M.V. and S.V. Nabozhenko, B. Keskin).

\section{Chrysolina marginata (Linnaeus, 1758)}

Material. Çorum Prov., Büget, 40³7'654"N / 3501'653"E, $1400 \mathrm{~m}$ 4.06.2009, 1 ex. (leg. M.V. and S.V. Nabozhenko, B. Keskin, I.V. Shokhin).

\section{Chrysolina sahlbergi (Ménétriés, 1832)}

Material. Corum Prov, Boğazkale, Hattuşa, 4001'47.2"N 34 $37^{\prime} 26.7^{\prime \prime}$ E, 1090 m, 12-13.04.2014, 1 ex. (leg. M.V. and S.V. Nabozhenko, B. Keskin); Amasia, $40^{\circ} 38^{\prime} 03^{\prime \prime} \mathrm{N} / 35^{\circ} 50^{\prime} 22^{\prime \prime} \mathrm{E}, 17.04 .2014,1$ ex. (leg M.V. and S.V. Nabozhenko, B. Keskin).

\section{Chrysolina sellata Weise, 1894}

Material. Muğla Prov., Babadağ Ridge, Fethiye Distr., above Ovacık, 36⒊ $31^{\prime} 59^{\prime \prime} \mathrm{N} / 2^{\circ} 11^{\prime} 26^{\prime \prime} \mathrm{E}, 1300$ m, 13-15.04.2008, 1 ex. (leg. M.V. Nabozhenko, B. Keskin).

\section{Chrysolina gypsophilae (Küster, 1845)}

Material. Isparta Prov., Eğırdır town, near Eğırdır lake, 12.05.2009, 1 ex. (leg. M.V. and S.V. Nabozhenko, B. Keskin).

\section{Chrysolina orientalis (Olivier, 1807)}

Material. Isparta Prov., Eğırdır town, near Eğırdır lake, 12.05.2009, 1 ex. (leg. M.V. and S.V. Nabozhenko, B. Keskin).

\section{Chrysolina herbacea alacris Bechyne, 1950}

Material. Van Prov., Erekdağ, $38^{\circ} 25^{\prime} 53.1^{\prime \prime} \mathrm{N} / 43^{\circ} 29^{\prime} 03.6^{\prime \prime} \mathrm{E}, 2077-$ 2600 m, 1.06.2013, 2 ex. (leg. M.V. and S.V. Nabozhenko, B. Keskin, A. Pektaş).

\section{Chrysolina salviae sculptipennis Faldermann, 1837}

Material. Sinop Prov., Boyabat Distr., Dumanlı Dağ, 41 $25^{\prime} 191^{\prime \prime} \mathrm{N}$ $34^{\circ} 43^{\prime} 450^{\prime \prime}$ E, $938 \mathrm{~m}, 1.06 .2009$, 1 ex. (leg. M.V. and S.V. Nabozhenko, B. Keskin).
Chrysolina grata (Faldermann, 1837)

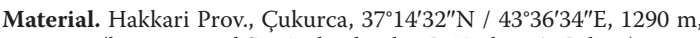
4.06.2013, 2 ex. (leg. M.V. and S.V. Nabozhenko, B. Keskin, A. Pektaş).

Phratora horioni (Mohr, 1968)

Material. Bitlis Prov., 3 km NE Tatvan, Van Lake coast, 24-26.04.2009, 1 ex. (leg. M.V. and S.V. Nabozhenko).

Phratora vitellinae (Linnaeus, 1758)

Material. Çamlıbeyli Pass between Tokat and Sivas Provinces, $39^{\circ} 57^{\prime} 33.66^{\prime \prime} \mathrm{N} / 36^{\circ} 31^{\prime} 33.92^{\prime \prime} \mathrm{E}, 16.04 .2014,1 \delta^{\hat{\gamma}}$ (leg. M.V. and S.V. Nabozhenko, B. Keskin).

\section{Hydrothassa flavocincta (Brullé, 1832)}

Material. Turkey, Mus Prov., Varto, $39^{\circ} 07^{\prime} \mathrm{N} / 41^{\circ} 27^{\prime} \mathrm{E}, 1450 \mathrm{~m}, 16-$ 17.05.2009, 2 ex. (leg. I.V. Shokhin, D.G. Kasatkin).

Remark. A size of this species was given as $3.4-4.4 \mathrm{~mm}$ [Warchałowski, 2003], but it is correct only for females. A size of males is $2.8-3 \mathrm{~mm}$.

\section{Neophaedon pyritosus (Rossi, 1792)}

Material. Antalya Prov., Korkuteli Distr., Ulucak, 36 $58^{\prime} 707^{\prime \prime} \mathrm{N} /$ 30 09'691"E, 1111 m, 10.05.2009, 1 ex. (leg. M.V. and S.V. Nabozhenko, B. Keskin).

\section{Gonioctena fornicata (Brüggeman, 1873)}

Material. Mus Prov., Varto, $39^{\circ} 07^{\prime} \mathrm{N} / 41^{\circ} 27^{\prime} \mathrm{E}, 1450 \mathrm{~m}, 16-17.05 .2009$ 1 ex. (leg. I.V. Shokhin, D.G. Kasatkin); Tokat env., 17.04.2014, 2 ex. (leg. M.V. and S.V. Nabozhenko, B. Keskin).

\section{Gonioctena linnaeana (Schrank, 1781)}

Material. Tunceli Prov., Pülümür, 28-29.05.2009, 3 ex. (leg. I.V. Shokhin, D.G. Kasatkin).

Remarks. These 3 specimens are represented with ab. nigricollis Westhoff, 1882, having black prothorax and fulvous elytra with 5 black spots (1 male and 1 female) and ab. kraatzi Westhoff, 1882 with black prothorax and entirely fulvous elytra (1 male), both described from Westphalia (Germany). These color forms are very rare and practically unknown from European part of Russia and the Caucasus. The species is widely distributed in the Northern Caucasus, recorded for Georgia and Turkey, but not found in Armenia and Azerbaijan. In the Caucasus the species usually has more or less bicolor prothorax. The cited above locality from East Turkey is mostly southern part of its range and very possibly it is a new subspecies. Males have parallel-sided main part of aedeagus, while aedeagus of typical G. linnaeana distinctly narrowed to base. However, I have no enough material for description.

Colaphellus sophiae (Schaller, 1783)

Material. Karaman Prov., Ayrancı Distr., $10 \mathrm{~km} \mathrm{~S}$ Kıraman, $37^{\circ} 11^{\prime} 851^{\prime \prime} \mathrm{N} / 33^{\circ} 59^{\prime} 208^{\prime \prime} \mathrm{E}, 1962 \mathrm{~m}, 19.04 .2008,2$ ex. (leg. M.V. Nabozhenko).

\section{Entomoscelis adonidis (Pallas, 1771)}

Material. Corum Prov., Büget, 40 37'654" N / 3501'653"E, 1400 m, 4.06.2009, 1 ex. (leg. M.V. and S.V. Nabozhenko, B. Keskin, I.V. Shokhin). 
Galeruca spectabilis Faldermann, 1837

Material. Malatya Prov., subdesert, 38 38 $48.9^{\prime \prime} \mathrm{N} / 38^{\circ} 19^{\prime} 44.1^{\prime \prime} \mathrm{E}$, 740 m, 21.05.2010, 1 ex. (leg. M.V. and S.V. Nabozhenko, B. Keskin).

\section{Galeruca interrupta armeniaca Weise, 1886}

Material. Antalya Prov., Korkuteli Distr., Ulucak, 36 $58^{\prime} 707^{\prime \prime} \mathrm{N}$ 30 09'691"E, $1111 \mathrm{~m}, 10.05 .2009$, 9 ex. (leg. M.V. and S.V. Nabozhenko, B. Keskin); Tunceli Prov., Pülümür, 28-29.05.2009, 1 ex. (leg. I.V. Shokhin, D.G. Kasatkin); Van Prov., Erekdağ, $38^{\circ} 25^{\prime} 53.1^{\prime \prime} \mathrm{N} / 43^{\circ} 29^{\prime} 03.6^{\prime \prime} \mathrm{E}, 2077-$ $2600 \mathrm{~m}, 1.06 .2013,1$ ex. (leg. M.V. and S.V. Nabozhenko, B. Keskin A. Pektaş).

Diorhabda fischeri Faldermann, 1837

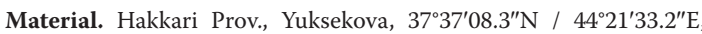
2000 m, 5.06.2013, 1 ex. (leg. M.V. and S.V. Nabozhenko, B. Keskin, A. Pektaş).

\section{Exosoma thoracicum Redtenbacher, 1843}

Material. Van Prov., S Başkale, 38 01'57.9"N / 4400'11.0"E, 2400 m, 6-7.06.2013, 4 ex. (leg. M.V. and S.V. Nabozhenko, B. Keskin, A. Pektaş).

Luperus discolor Faldermann, 1837

Material. Corum Prov., Büget, 40 37 $654^{\prime \prime} \mathrm{N} / 35^{\circ} 01^{\prime} 653^{\prime \prime} \mathrm{E}, 1400 \mathrm{~m}$ 4.06.2009, 7 ex. (leg. M.V. and S.V. Nabozhenko, B. Keskin).

\section{Altica hampei (Allard, 1867)}

Material. Hakkari Prov., Berçelan Yaylası, $37^{\circ} 38^{\prime} 11.6^{\prime \prime} \mathrm{N} / 43^{\circ} 45^{\prime} 20.2^{\prime \prime} \mathrm{E}$ 2700 m, 3.06.2013, 1 ex. (leg. M.V. and S.V. Nabozhenko, B. Keskin, A. Pektas); Bitlis Prov., Nemrut volcan, $38^{\circ} 36^{\prime} 20.8^{\prime \prime} \mathrm{N} / 42^{\circ} 15^{\prime} 23.1^{\prime \prime} \mathrm{E}, 2330 \mathrm{~m}$ 7-8.06.2013, 2 ex. (leg. M.V. and S.V. Nabozhenko, A. Pektaş).

\section{Derocrepis (Aeschrocnemis) serbica? osmanica Nadein, 2011}

Material. Bitlis Prov., 3 km NE Tatvan, Van lake coast, 24-26.04.2009, 1 ex. (leg. M.V. and S.V. Nabozhenko).

Remarks. The genus Derocrepis Weise, 1886 was traditionally divided to subgenus s. str., including species with developed wings and subgenus Aeschrocnemis Weise, 1888 , in which wings are absent. But recently the latter subgenus was erected to independent genus [Nadein, 2011]. This author divides Aeschrocnemis from Derocrepis with 4 characters: 1 - "in quadrate or subquadrate pronotum versus transverse"; 2 - "absence of hind wings"; 3 - "sutural row of elytral punctures not impressed"; 4 - "structure of aedeagus" [Nadein, 2011: 245].

The first two characters were used in the original description of Aeschrocnemis. The character 1 means only that pronotum in Aeschrocnemis is less transverse than in Derocrepis. Nadein indicates measurements of prothorax for all species (IP) included in his work, but only for 1 species (Ae. delagrangei) it is more or less quadrate (IP $=0.95-1.17$ ), for 7 species IP is less than 1.2 and for 16 species IP larger than 1.2 and sometimes reach 1.35 . But in D. (s. str.) rufipes (Linnaeus, 1758) this index is about 1.5 (1.42-1.56, I measured 10 specimens). So this character is not good for genera dividing.

The second character is really very distinct, but also can not been used for separation of genera. In all large genera (Longitarsus Berthold, 1827, Aphthona Chevrolat, 1836, Chaetocnema Stephens, 1831, Dibolia Latreille, 1829, Psylliodes Berthold, 1827) apterous forms are known.

The third character is very variable and might be used only on species level.

The fourth character was used without any explanation. I compare aedeagi of Derocrepis and Aeschrocnemis and can confirm that all they are of the same type, only different form.

Besides, in Nadein's publication 2 new subgenera are described: Hirticnemis with haired elytra and Nudicnemis with "bare" elytra. But in reality all Aeschrocnemis have hairs on elytra, but often they are strongly reduced and distinct only on apices and sides of elytra. I think that these new subgenera are only more or less natural groups of species.

Nudicnemis differs from Aeschrocnemis only in sculpture of head, but specimen in my hands has frontal tubercles as in Aeschrocnemis, but frontal ridge as in Nudicnemis. It is very alike at Ae. osmanica Nadein, 2011 except color of head, but has also much similarity with Ae. turcica Nadein et Gök, 2009. But I accept my specimen only as a subspecies of $D$. (Ae.) serbica (Kutschera, 1860).

It is necessary to mention that $K$. Nadein accepts all subspecies of $D$. (Ae.) serbica as independent species, but that is very doubtful. Possibly a few species described by K. Nadein are also subspecies of $D$. (Ae.) serbica.

A specimen in question was collected near Van Lake in Eastern Turkey. K. Nadein indicated a species just near Van on fig. 35, but didn't indicate its name.

\section{Cassida undecimnotata Gebler, 1834}

Material. Muş Prov., Buğlan Pass, 7 km E Solhan, $38^{\circ} 56^{\prime} \mathrm{N} / 41^{\circ} 07^{\prime} \mathrm{E}$, 1725-1930 m, 19-22.05.2009, 5 ex. (leg. I.V. Shokhin, D.G. Kasatkin).

\section{Cassida brevis Weise, 1881}

Material. Mus Prov., Buğlan Pass, 7 km E Solhan, 38 $56^{\prime} \mathrm{N} / 41^{\circ} 07^{\prime} \mathrm{E}$, 1725-1930 m, 19-22.05.2009, 3 ex. (leg. I.V. Shokhin, D.G. Kasatkin).

\section{References}

Catalogue of Palaearctic Coleoptera. Vol. 6. Chrysomeloidea. (I. Löbl, A. Smetana eds). 2010. Stenstrup: Apollo Books. 924 p.

Lopatin I., Chikatunov V. 1997. The Cryptocephalinae (Coleoptera, Chrysomelidae) of Israel, Jordan and the Sinai part of Egypt. Israel Journal of Entomology. 31: 97-119.

Nadein K. 2011. Revision of the genus Aeschrocnemis Weise, 1888 (Coleoptera, Chrysomelidae). Zoosystematics and Evolution. 87(2): 243-289.

Warchałowski A. 2003. Chrysomelidae. The leaf-beetles of Europe and the Mediterranean area. Warszawa: Natura optima dux Foundation. $600 \mathrm{p}$. 